\title{
JUVENILE, PRISONS, AND JUSTICE: HOW DO CORRECTIONAL AGENCIES PROVIDE LEGAL ASSISTANCE FOR CHILDREN IN CONFLICT WITH THE LAW?
}

\author{
Syaiful Anwar \\ Child and Women Protection Studies Center, Bandung, Indonesia \\ Mardella Galih* \\ Correctional Center, Ministry of Law and Human Rights Republic of Indonesia, \\ Bogor, West Java, Indonesia \\ *Email: mardella.galih@gmail.com
}

The Juvenile Justice System in Indonesia has a special feature where a child facing the law in criminal justice must receive special protection by law enforcers. One of them is the Correctional Center which has an important role in providing input from the police, prosecutors and courts as a form of realization of the protection of children's rights. Children who are included in the group whose rules are in the national and international human rights instruments must receive special protection by providing legal assistance and the state must be responsible for the fulfillment of these special rights. The issues raised in this paper are: What is meant by children dealing with the law and

The Indonesian Journal of International Clinical Legal Education DOI: https://doi.org/10.15294/ijicle.v3i2.46171

Submitted: Nov 11, 2020 Revised: Jan 30, 2021 Accepted: Feb 22, 2021 Available online at https://journal.unnes.ac.id/sju/index.php/iccle

(C) 2021 Authors. This work is licensed under a Creative Commons AttributionShareAlike 4.0 International License (CC BY-SA 4.0). All writings published in this journal are personal views of the authors and do not represent the views of this journal and the author's affiliated institutions. 
what is the form of legal assistance by correctional institutions (BAPAS) for children dealing with the law. The method used in writing this paper is descriptive qualitative analysis using primary legal material data, secondary legal materials, and other literature study materials.

Keywords: BAPAS; Children; Correctional Institution; Justice; Legal Protection; Legal Assistance

\section{INTRODUCTION}

For the survival of a nation and state, a successor is needed, namely children. In the 1945 Constitution, children are one of the important elements in the state, where the state has an obligation to provide guarantees for the rights of all children to live, live, grow, develop and have the right to be protected from evil acts and other forms of discrimination. This obligation is a form of protection and protection for children which aims to welcome a better future for children. Children have the potential to play a role in increasing the progress and development of the country in the future. ${ }^{1}$ Children need special legal protection in order to increase the protection of children against their physical or psychological.

The more years the number of cases involving children in it, it does not necessarily equate the form of accountability of children with adults as perpetrators. The actions of children in conflict with the law are caused by many factors, including: family, social environment, and the failure of the state to fulfill children's rights. Children are part of a vulnerable group that must receive more legal protection from the state in order to ensure their rights needs, this has been regulated in human rights legal instruments in Indonesia and internationally.

One form of legal protection that is more for children dealing with the law is that in terms of handling the case, it should not be equated with the case of adult perpetrators. This legal protection has been regulated in national and international human rights legal instruments, namely Law Number 11 of 2012 concerning the Juvenile Criminal Justice System, Law Number 35 of 2016 concerning Child Protection, and/or international human rights legal instruments such as the Convention on Child Protection. Children's Rights, UN Standard Minimum Rules Regarding the Administration of Justice for Children (Beijing Rules) and UN Guidelines for the Prevention of Child Crime (The Riyadh Guidelines). However, it is very unfortunate that until now there are still violations of the rights of children in conflict with the law. One of them

1 Susilowati. 2008. Upaya Meminimalisasi Penggunaan Pidana Penjara Bagi Anak. Semarang, Universitas Diponogoro. pp 9-10. 
is the handling of children dealing with the law which is still equated with the process of handling cases with adult perpetrators.

In the United States, children get special legal protection or what is known as juvenile court, some of the special protections include the following:

a. The principle of presumption of innocence, if a child commits a crime then it should not be called a criminal, but as an act of delinquency, namely the inability of the child to be responsible for his actions.

b. For children's cases, courts are required to decide cases in a shorter time than ordinary cases.

c. If a child enters a correctional institution, it is considered as a form of guidance to recover back to its initial condition.

d. Performing separation during the course of the legal process against child perpetrators and adult criminal offenders.

e. The period of coaching for child offenders in correctional institutions is faster than adult offenders

$\mathrm{f}$. The trial process is closed to the public, that is, it can only be attended by the family or parties whose testimony is required at the trial.

The purpose of making correctional institutions in Indonesia is to create an independent attitude for prisoners after leaving prison. The criminal justice system is a series of criminal law enforcement processes for maintaining public order, the implementation of which is carried out starting from the police, prosecutors, courts, to correctional institutions. The system aims at the synergy of the law enforcement process to achieve justice.

In the criminal justice system there is a final process involving correctional institutions, in this case one of which is carried out by (BAPAS). This institution is regulated in Law Number 12 of 1995 concerning Corrections. The Correctional Center (BAPAS) is an institution in charge of the implementation of the guidance for correctional clients. ${ }^{2}$ One of the correctional clients referred to in the law is a child who is the guidance of BAPAS. ${ }^{3}$

The Penitentiary Agency (BAPAS) has a role in legal assistance to children dealing with the law regulated in Government Regulation Number 1 of 1999 concerning the Guidance and Guidance of Correctional Inmates. BAPAS workers who carry out tasks in terms of guiding Correctional Officers who carry out the task of guiding children's clients are called community counselors. ${ }^{4}$

Based on this background, the problems in this study include, first, an analysis of what is meant by children in conflict with the law, and

Article 1 (4) Undang-Undang Nomor 12 Tahun 1995 tentang Pemasyarakatan. Article 1 (9) Undang-Undang Nomor 12 Tahun 1995 tentang Pemasyarakatan. Article 1 (6) Undang-Undang Nomor 12 Tahun 1995 tentang Pemasyarakatan. 
second, what is the form of legal assistance from the Correctional Institution (BAPAS) for children in conflict with the law.

\section{CHILDREN CONFLICT WITH THE LAW: JUVENILE DELINQUENCY AND THE LEGAL PROTECTION}

Children in conflict with the law are children who are in conflict with the law, children who are victims of criminal acts, and children who are domiciled as witnesses of criminal acts. ${ }^{5}$ Ensuring the survival of children is a form of parental responsibility that must be carried out. Children are a group of young people who have an important position, have special characteristics, and are entrusted by God to parents to get education and protection so that they can become the nation's successors. Wagiati Soetodjo divides 3 (three) phases of children ${ }^{6}$, as follows:

a. Childhood phase, age 0 (zero) -7 (seven)

b. Childhood phase, age 7 (seven) to 14 (fourteen) years old

c. Adolescent phase, age 14 (fourteen) to 21 (twenty one) years.

In positive law, Indonesia has regulated the protection of children as contained in various laws and regulations, including: Law Number 3 of 1997 concerning Juvenile Courts, Law Number 39 of 1999 concerning Human Rights and Law Number 23 of 2002 in conjunction with Article 64 of Law No. 35 of 2014 concerning Child Protection. However, in its implementation the juvenile criminal justice system in Indonesia still faces various challenges. These challenges include detaining child perpetrators, a long judicial process starting from investigations, prosecutions, courts, to correctional institutions which result in trauma and negative impacts on children. ${ }^{7}$

According to Law Number 35 of 2014 concerning Child Protection, a child is someone who is not yet 18 (eighteen) years old, Meanwhile, according to Article 1 Paragraph (3) of the Child Criminal Justice System Law (SPPA), a child in conflict with the applicable Law hereinafter referred to as child is a child who is 12 (twelve) years old, but not yet 18 (eighteen) years old who is suspected of committing a crime.

The unlawful act committed by most children is an act that was initially just a juvenile delinquency which led to a criminal act which in the end required serious legal action. ${ }^{8}$ Therefore, the hope of the nation

5 Article 1 ayat (2) UU No. 11 Tahun 2012 tentang Sistem Peradilan Pidana Anak

6 Wagiati Soetodjo, 2010, Hukum Pidana Anak, Bandung: PT. Refika Aditama; pp. 7-8.

7 Marlina, 2009; Peradilan Pidana Anak di Indonesia Pengembngan Konsep Diversi dan Restorative Justice; Bandung : PT. Refika Aditama, p 1.

8 Soedarto, 1983; Hukum Pidana dan Perkembangan Masyarakat; Bandung: PT. Sinar Baru, p. 32. For more comprehensive comparison concerning Juvenile 
to have a quality next generation is hampered. The process of finding a child's identity often makes children fall into negative things that can harm themselves.

Law enforcement officials in giving and making decisions that reflect a sense of justice are guided by the Juvenile Justice System. This is related to the decision to impose criminal sanctions on children, it must be the right decision to be in the best interests of the child or vice versa. As Sudarto's opinion is quoted by Sambas, punishment is a suffering that is intentionally given to people who have committed acts with certain conditions that must be met. ${ }^{9}$

There are 3 (three) well-known juvenile justice paradigms, including the following:

a. individual development paradigm, focusing on the problems faced by child offenders, not on the behavior/losses caused;

b. the retributive paradigm, focusing on the imposition of sanctions, the determination of which is carried out as long as the child offender undergoes a criminal process;

c. restorative paradigm, focusing on imposing sanctions which involve the victim to be actively involved in the judicial process, indicators of achieving the goal of imposing sanctions are achieved by seeing whether the victim has been restored, victim satisfaction and so on. ${ }^{10}$

In the criminal justice system, children must seek a diversion process before taking the formal route, namely a settlement of children's cases from the criminal justice process to a process outside of criminal justice. Diversion efforts must be carried out starting from the level of investigation, prosecution, to the examination of children's cases in the district court.

If the diversion is not carried out by investigators, public prosecutors, or judges, the legal consequences of criminal sanctions cannot be imposed on him. This is in accordance with the decision issued by the Constitutional Court in the Decision of the Constitutional Court Number 110/PUU-X/2012. Handling and good and appropriate treatment of children who commit crimes is very influential on the psychology of

Delinquency and Justice, please also see Davies, S. G., \& Robson, J. (2016). Juvenile (In) Justice: Children in Conflict with the Law in Indonesia. Asia-Pacific Journal on Human Rights and the Law, 17(1), 119-147; Aji, W. S. (2019). The Implementation of Diversion and Restorative Justice in the Juvenile Criminal Justice System in Indonesia. JILS (Journal of Indonesian Legal Studies), 4(1), 73 88; Erdianti, N., \& Al-Fatih, S. (2019). Fostering as an Alternative Sanction for Juveniles in the Perspective of Child Protection in Indonesia. JILS (Journal of Indonesian Legal Studies), 4(1), 121-128.

9 Sambas, Nandang; 2010, Pembaruan Sistem Pemidanaan Anak di Indonesia; Bandung: Refika Aditama, p 12. See also Becroft, A. J. (2006). Children and young people in conflict with the law: Asking the hard questions. Juvenile and Family Court Journal, 57(4), 1-37.

10 Wahyudi, S, 2011; Implementasi Diversi dalam Pembaharuan Sistem Peadilan Pidana Anak di Indonesia; Purwokerto: Genta Publishing, pp 38-39. 
children. Therefore, special legal assistance is needed in handling cases of children who are in conflict with the law at the level of the police, prosecutors, and courts. In addition, it is necessary to underline that criminal acts with children as perpetrators not only harm the children themselves but also harm the community.

In the trial, the decision against the child is in the hands of the judge. Judges who play a role in giving decisions on children's cases, have a crucial role in determining the fate of children in the future. As stated by Purniati and colleagues in a book written by Sri Sutatiek, that the nature of the justice system in Indonesia gives judges authority as the institution that determines the fate of children. ${ }^{11}$ Juvenile judges are required to consider the future interests of children, in making decisions related to children's cases. This is as conveyed by the late Prof. Sudarto that although the bill states that the juvenile court is concerned with the welfare of the child in addition to the interests of the community, the interests of the child must not be sacrificed for the sake of the community. ${ }^{12}$

Whereas in the process of resolving cases of children who are in conflict with the law, they must prioritize the goodness and interests of the children themselves, which aim to prosper and protect children from negative stigma as a result of the legal process they go through. Juvenile judges as judicial officials have the authority by law to judge and as determinants of the fate of children must prioritize the principle of the best interests of children so that the success of juvenile justice can be achieved properly.

\section{FORMS OF ASSISTANCE BY CORRECTIONAL SERVICES (BAPAS) FOR CHILDREN IN CONFLICT WITH THE LAW}

The form of legal assistance for children in conflict with the law was first formulated in Law Number 23 of 2002 concerning Child Protection (hereinafter UUPA). Children who are perpetrators of criminal acts are often considered to be still free to roam outside the correctional institution, even though child offenders receive assistance from their families and can still carry out daily activities as usual. The task of

11 Sutatiek; 2013; Rekonstruksi Sistem Sanksi dalam Hukum Pidana Anak di Indonesia, Urgensi Penerbitan Panduan Pemidanaan (The Sentencing Guidlines) untuk Hakim Anak; Yogyakarta: Aswaja Presindo; p 29.

12 Muladi dan Barda Nawawi; 2010; Bunga Rampai Hukum Pidana; Bandung: PT. Alumni;. P. 120. 
BAWAS is regulated in Law Number 11 of 2012 concerning the Juvenile Criminal Justice System.

Some of the roles of BAPAS in legal assistance include the following ${ }^{13}$ :

a. Normative Role

It is a role where everyone can carry out their respective rights and obligations, or what is called a full form of law enforcement.

b. Ideal Role

Is a role in which everyone carries out the rules that have been set, which are based on ideal values or should be carried out according to their position in a system.

c. Factual Role

Is a role which is carried out by a person or institution based on direct reality in the field as well as seen from concrete social life.

Legal assistance to children is not only carried out by BAPAS, according to Law no. 11 of 2012 there are several companions namely:

1. Companion, is a person who has the trust of the child so that he can provide assistance to him during the legal process.

2. Community advisor, is a community supervisor or functional law enforcement official who performs tasks in community research, guidance, supervision, and assistance to children inside and outside the criminal justice process.

3. Social welfare workers are people who have received professional education and training in order to be able to handle service tasks and handle social problems and/or someone who works, both in government and private institutions, whose scope of work is in the field of children's social welfare.

4. Professional social workers are people who do work, in government or private institutions, who have the competence and profession of social work and care in social work obtained due to education, training, and/or experience in social work practices in order to be able to carry out service tasks and handle children's cases. dealing with the law.

5. Family, are parents consisting of father, mother, and/or other family members who have the trust of the child.

6. Guardian, is a person or entity that in its implementation provides care like a parent to a child.

BAPAS's duties in guiding and assisting child victims are regulated in Law Number 11 of 2012 concerning the Juvenile Criminal Justice System, including attending trials as members of the juvenile court and providing guidance to clients (children in conflict with the law). In addition to this, BAPAS also has other roles and functions, namely conducting community research that is useful as a material for

13 Soekanto, Soerjono; 1980; Penegakan Hukum; Bandung : PT. Bina Cipta; p. 220. 
investigators to consider in the diversion process at the police and court levels.

In addition, judges use community research reports as consideration in making decisions on cases of children who are in conflict with the law. ${ }^{14}$ If this is not done by the judge, the juridical impact will be in the form of a decision null and void. ${ }^{15}$ Like the opinion issued by Sambas, for children who are in conflict with the law who go through the stages of the court without a companion or one of them is BAPAS, it is possible that the child will fall back into committing a crime in the same case or in a different case. ${ }^{16}$

BAPAS is an officer who participates in the trial process of children who are in conflict with the law from the process of arresting children to entering prisons. Based on this, BAPAS has a central position in the juvenile justice process dealing with the law. In general, the role of BAPAS in the juvenile justice process in conflict with the law must be a legal assistant from three stages, namely the pre-trial stage (preadjudication) is the investigation, the stage during the trial (adjudication) is assisting in the trial and the post-trial stage (post-trial). adjudication) is to supervise and guide children in conflict with the law. ${ }^{17}$

Based on this description, it can be concluded that the role and function of BAPAS in the process of handling cases of children in conflict with the law is very important to realize the objectives of the juvenile criminal justice system.

The community research report aims to provide a fair decision chosen by judges and can create a criminal justice system that guarantees the protection of the best interests of children, therefore there is no bad stigma against children in conflict with the law. In the general explanation of the Law on the Criminal Justice System, it is stated that the purpose of the juvenile criminal justice system is to create a judiciary that truly guarantees the protection of the best interests of children who are in conflict with the law who are the nation's successors.

In deciding a child case, judges are required to pay attention to several things, including those related to community research reports made by BAPAS. The report contains the reasons for the child and the purpose of the child committing a crime. The obligation to make

14 Article 60 Ayat (3) Undang-Undang Nomor 11 Tahun 2012 Tentang Sistem Peradilan Pidana Anak.

15 Article 60 Ayat (4) Undang-Undang Nomor 11 Tahun 2012 Tentang Sistem Peradilan Pidana Anak.

16 Sambas, Nandang; 2013; Peradilan Pidana Anak di Indonesia dan Instrumen Internasional Perlindungan Anak serta Penerapannya; Yogyakarta: Graha Ilmu; p.35.

17 Nashriana; 2012; Perlindungan Hukum Pidana Bagi Anak di Indonesia; Depok: Raja Grafindo Persada; pp. 110-116; Ariyani, W., \& Susilowati, H. (2021). The Challenges Faced by Community Advisors in Diverting Children who are in Conflict With the Law. KnE Social Sciences, 203-211. 
community reports must be carried out by BAPAS. The rules are in Article 13 letter (b) Joint Decree of the Chief Justice of the Supreme Court, the Attorney General, the Chief of Police, the Minister of Law and Human Rights, the Minister of Social Affairs, and the Minister of Women's Empowerment and Child Protection which states that BAPAS has an obligation in terms of making a correctional research report. ${ }^{18}$

The contents of the report made by BAPAS in terms of the purposes of the trial include the following ${ }^{19}$ :

1. Personal data of children, education, family, education, and social life;

2. Reason for committing a crime;

3. The condition of the victim if the crime involves the body or life;

4. Other things deemed necessary;

5. Minutes of diversion events; and

6. Conclusions and recommendations.

Hawnah Scaft, quoted in Anggraeni's research ${ }^{20}$ stated that: the success or failure of juvenile justice is much more dependent on the quality of the BAPAS officers, rather than the judges. Juvenile courts that do not have a special institution for probationary supervision that is tasked with guiding wisely and affectionately into the environment of children's lives and providing guidance for pure standards of thought for children regarding right life will only result in the function of juvenile justice being blurred if do not want to be in vain.

The achievement of the objectives of juvenile justice is due to the quality of the BAPAS officers, which in this case is meant for the legal assistance process. Because judges in their judgments are based on the quality of community research reports, they have a great influence on the fate of children.

In the implementation of child protection in the Juvenile Criminal Justice System, human rights must be considered, especially to fulfill, respect, and protect children based on Pancasila and the 1945 Constitution, which have the following principles ${ }^{21}$ :

1. The principle of non-discrimination,

2. The principle of prioritizing the best interests of the child,

3. The principle of the right to life, survival and development,

4. The principle of respect for the opinion of the child.

18 Gultom, Maidin; 2013; Perlindungan Hukum terhadap Anak; Bandung: PT. Refika Aditama; p.125.

19 U.R, Anggraeni; Peranan Pembimbing Kemasyarakatan di dalam Sistem Peradilan Pidana Anak di Kota Bengkulu;. Jurnal Supermasi Hukum Universitas Bengkulu Vol. 22 No.1. Januari 2013; p. 116

20 KOMNAS HAM dan AusAID; 2007; Pembangunan Berbasis Hak Asasi Manusia: Sebuah Panduan, Kerja sama antara Komisi Nasional Hak Asasi Manusia (KOMNAS HAM) dengan Australian Government (AusAID), p. 8.

21 Soekanto, Soerjono; 2008; Faktor-faktor yang Mempengaruhi Penegakan Hukum; Jakarta: Raja Grafindo Persada; p. 31. 
To strengthen the role of BAPAS in terms of legal assistance to children in conflict with the law, BAPAS no longer carries out its duties alone. However, it leads to the synergy of the components of community officers. $^{22}$ This synergy should continue to be strengthened in every process of the juvenile justice system while still paying attention to the main tasks of each existing institution.

\section{CONCLUSION}

Children in conflict with the law are children who are in conflict with the law, children who are victims of criminal acts, and children who are domiciled as witnesses of criminal acts. One of the institutions that play a role in legal assistance to children in conflict with the law is the Correctional Institution (BAPAS). BAPAS is an officer who participates in the trial of children who are in conflict with the law from the process of arresting children to entering prisons. Based on this, BAPAS has a central position in the juvenile justice process dealing with the law. In general, the role of BAPAS in the juvenile justice process in conflict with the law must be a legal assistant from 3 stages, namely the pre-trial stage (pre-adjudication) is the investigation, the stage during the trial (adjudication) is assisting in the trial and the post-trial stage (post-trial). adjudication) is to supervise and guide children in conflict with the law. Thus, from the existence of BAPAS, the justice process can still be carried out properly in accordance with the applicable laws and regulations and can reduce the psychological impact that can befall the child himself.

\section{REFERENCES}

Aji, W. S. (2019). The Implementation of Diversion and Restorative Justice in the Juvenile Criminal Justice System in Indonesia. JILS (Journal of Indonesian Legal Studies), 4(1), 73-88.

Ariyani, W., \& Susilowati, H. (2021). The Challenges Faced by Community Advisors in Diverting Children who are in Conflict With the Law. KnE Social Sciences, 203-211.

Becroft, A. J. (2006). Children and young people in conflict with the law: Asking the hard questions. Juvenile and Family Court Journal, 57(4), 1-37.

22 Article 61 Undang-undang No. 11 Tahun 2012 tentang Sistem Peradilan Pidana Anak. 
Davies, S. G., \& Robson, J. (2016). Juvenile (In) Justice: Children in Conflict with the Law in Indonesia. Asia-Pacific Journal on Human Rights and the Law, 17(1), 119-147.

Erdianti, N., \& Al-Fatih, S. (2019). Fostering as an Alternative Sanction for Juveniles in the Perspective of Child Protection in Indonesia. JILS (Journal of Indonesian Legal Studies), 4(1), 121128.

KOMNAS HAM \& AusAID. (2007). Pembangunan Berbasis Hak Asasi Manusia: Sebuah Panduan, Kerja sama antara Komisi Nasional Hak Asasi Manusia (KOMNAS HAM) dengan Australian Government (AusAID). Jakarta: Komnas HAM.

Maidin, G. (2013). Perlindungan Hukum terhadap Anak. Bandung: PT. Refika Aditama.

Marlina, M. (2009). Peradilan Pidana Anak di Indonesia Pengembngan Konsep Diversi dan Restorative Justice. Bandung: PT. Refika Aditama.

Muladi, M., \& Arief, B. N. (2010). Bunga Rampai Hukum Pidana. Bandung: PT. Alumni.

Nandang, S. (2010). Pembaruan Sistem Pemidanaan Anak di Indonesia. Bandung: Refika Aditama.

Nandang, S. (2013). Peradilan Pidana Anak di Indonesia dan Instrumen Internasional Perlindungan Anak serta Penerapannya. Yogyakarta: Graha Ilmu.

Nashriana, N. (2012). Perlindungan Hukum Pidana Bagi Anak di Indonesia. Jakarta: Raja Grafindo Persada.

Republic of Indonesia. (1995). Undang-Undang Nomor 12 Tahun 1995 tentang Pemasyarakatan.

Republic of Indonesia. (2012). Undang-undang No. 11 Tahun 2012 tentang Sistem Peradilan Pidana Anak.

Republic of Indonesia. (2014). Undang-Undang Nomor 35 Tahun 2014 tentang Perlindungan Anak.

Soedarto, S. (1983). Hukum Pidana dan Perkembangan Masyarakat. Bandung: PT. Sinar Baru.

Soerjono, S. (1980). Penegakan Hukum; Bandung : PT. Bina Cipta.

Soerjono, S. (2008). Faktor-faktor yang Mempengaruhi Penegakan Hukum. Jakarta: Raja Grafindo Persada.

Susilowati, S. (2008). Upaya Meminimalisasi Penggunaan Pidana Penjara Bagi Anak. Semarang: Universitas Diponogoro.

Sutatiek, S. (2013). Rekonstruksi Sistem Sanksi dalam Hukum Pidana Anak di Indonesia, Urgensi Penerbitan Panduan Pemidanaan (The Sentencing Guidlines) untuk Hakim Anak. Yogyakarta: Aswaja Presindo.

Utami, R. A. Peranan Pembimbing Kemasyarakatan di dalam Sistem Peradilan Pidana Anak di Kota Bengkulu. Jurnal Supremasi Hukum, 22(1), 113-132. 
Wagiati, S. (2010). Hukum Pidana Anak. Bandung: PT. Refika Aditama. Wahyudi, S. (2011). Implementasi Diversi dalam Pembaharuan Sistem Peadilan Pidana Anak di Indonesia. Yogyakarta: Genta Publishing.

\section{Conflicting Interest Statement}

All authors declared that there is no potential conflict of interest on publishing this article.

\section{Funding}

None

\section{Publishing Ethical and Originality Statement}

All authors declared that this work is original and has never been published in any form and in any media, nor is it under consideration for publication in any journal, and all sources cited in this work refer to the basic standards of scientific citation.

Cite this article as:

Anwar, S., \& Galih, M. (2021). Juvenile, Prisons, and Justice: How Do Correctional Agencies Provide Legal Assistance for Children in Conflict with The Law?. The Indonesian Journal of International Clinical Legal Education, 3(2), 197-208. https://doi.org/10.15294/ijicle.v3i2.46171 